\title{
Bourdieu Perspektifiyle Bürokratik Çatışma Alanı ve Konut: Fransa'da Yeni Konut Politikasının İnşası
}

\author{
Umut Seren Yarmm ${ }^{1}$ \\ ORCID: 0000-0001-7799-1744
}

\author{
Eylem Beyazit ${ }^{2}$ \\ ORCID: 0000-0002-3432-5722
}

\author{
Muharrem Güneş3 \\ ORCID: 0000-0002-3187-8233
}

Öz

Konutun hem bir üretim hem de tüketim nesnesi olarak pek çok sosyal bilim alanında tartışıllyor olması şaşırtıcı değildir. Ekonomik alandan siyasal ve sosyolojik alana uzanan tartışmaların ekseni dönemsel olarak değişse de konutun neredeyse bütün rejimlerde "kullanışh" bir araç olduğu görülmektedir. Konut politikalarının inşa ve analiz sürecinde farklilıklar görülmektedir. Her ülke, rejim pratiği sonuçları açısından farklı pratik ve değerlendirmeler ortaya çıkarırken gerçek olan, konut sorununun hızla "hak" temelli bir insanlık sorunu olarak karşımızda durmasıdır. Bu çalışma Bourdieu'nün kavramsal araçların kullanarak, Fransız konut politikasının inşasında önemli kırılma noktaları olan tarihsel süreçleri ele almakta, konut politikaların bürokratik alan üzerinden analiz etmeyi amaçlamaktadır. Çalışmanın temel tezi, "görünmez" olarak da nitelenebilecek "bürokratik alanın" çatışmacı niteliklerinin konut politikasının belirlenmesi ve uygulanması sürecindeki yeri ve etkisinin belirleyiciliğidir. Bourdieu'nün alandaki araştırması temel alınarak konut politikası incelemelerinde çoklu aktör analizi yapılması önerilmektedir. Inş̧aat sektörünün kapitalistlerin çıkarları kadar bürokrasi alanındaki mücadelelerin ve yalnızca merkezin değil yerel güçlerin de çıkarlarının ve habituslarının etkili olduğu sonucuna varılmaktadır.

Anahtar Kelimeler: Pierre Bourdieu, konut politikası, bürokratik alan, devlet.

\footnotetext{
${ }^{1}$ Arş Gör., Hatay Mustafa Kemal Üniversitesi, E-mail: serenyarim@gmail.com

2 Dr. Öğr. Üyesi, Hatay Mustafa Kemal Üniversitesi, E-mail: eylmbyzt@gmail.com

${ }^{3}$ Prof. Dr., Hatay Mustafa Kemal Üniversitesi, E-mail: mgunes92@gmail.com

idealkent (c) Kent Araştırmaları Dergisi (Journal of Urban Studies)

http://idealkentdergisi.com

Geliş Tarihi Received Date: 25.06.2020 Kabul Tarihi Accepted Date: 08.12.2020
} 


\title{
Field of Bureaucratic Struggles and Housing with Bourdieu's Perspective: The Production of New Housing Policy in France
}

\author{
* \\ Umut Seren Yarım ${ }^{4}$ \\ ORCID: 0000-0001-7799-1744 \\ Eylem Beyazit ${ }^{5}$ \\ ORCID: 0000-0002-3432-5722 \\ Muharrem Güneş 6 \\ ORCID: 0000-0002-3187-8233
}

\begin{abstract}
It is not surprising that the house is discussed in many branches of social sciences because of its way of usage as an object of production and consumption. Although the axis of discussions extending from the economic field to the political and sociological fields changes periodically, the house issue continues to be a "useful" tool in almost all systems. There are differences in the construction and analysis process of housing policies. While each country develops different policies and takes different positions, it is necessary to consider the housing problem as a "right" based human problem. This study aims to consider the historical processes, which are important breaking points in the production of French housing policy, by using Bourdieu's conceptual tools, and aims to analyse housing policies through the bureaucratic field. The purpose of this paper is to specify the place and the influence of the conflict positions of the actors in the "invisible" bureaucratic field, through process of determining and implementing the housing policy. Based on Bourdieu's research in the field, a correspondence analysis is recommended in housing policy reviews. Consequently, the struggles in the bureaucracy and the interests and habitus of the local authorities are as effective as the interests of the capitalists in the construction sector.
\end{abstract}

Keywords: Pierre Bourdieu, housing policy, bureaucratic field, state.

\footnotetext{
${ }^{4}$ R. A., Hatay Mustafa Kemal University, E-mail: serenyarim@gmail.com

${ }^{5}$ Instructor Dr., Hatay Mustafa Kemal University, E-mail: eylmbyzt@gmail.com

${ }^{6}$ Prof. Dr., Hatay Mustafa Kemal University, E-mail: mgunes92@gmail.com

idealkent (c) Kent Araştırmaları Dergisi (Journal of Urban Studies)

http://idealkentdergisi.com

Geliş Tarihi Received Date: 25.06.2020 Kabul Tarihi Accepted Date: 08.12.2020
} 


\section{Giriş}

İnsanların sağlıklı ve onurlu bir hayat sürebilmeleri için barınma gereksinimini karşılayan konut, tüm ülke politikalarının ana konularından biri olarak sürekli gündemini korumaktadır. Geçmişten bugüne evrensel bir olgu olarak konut sorunu gerek gelişmiş gerekse gelişmekte olan ülkelerde bütünüyle çözüm bulunabilen bir sorun değildir. Konut sorununun boyutları ve niteliği genelleme yapılmaksızın ülkeden ülkeye, ülkelerin gelişmişlik düzeylerine ve sosyo-ekonomik yapılarına göre değişmektedir. Konutun temel bir ihtiyaç mı, dayanıklı bir tüketim metası $\mathrm{ml}$, bir yatırım aracı $\mathrm{ml}$, toplumsal hizmet ve refah sisteminin bir parçası mı ya da bütün hepsini içine alan bir olgu mu olduğu sorusu devletin bu sektörün müdahale edilmesi gereken bir üretim faaliyeti mi, özel sektöre devrettiği bir rant kapısı mı yoksa sosyal altyapı sunumu mu olduğuna karar vermesini gerektirir.

Hem temel bir ihtiyaç olarak refah devletinin ayrılmaz bir parçası olup hem de değişim değeri bulunan ve alınıp satılabilen bir piyasa malı olmasından dolayı kamu sektörü ve hükümetler konutu serbest piyasa mantı̆̆ına bırakmak istemedikleri gibi piyasanın görünmez elinin de çekilmesini tercih etmemektedirler. Devlet bu ekonomik alanda yalnızca bir düzenleyici ve/veya bir hakem olarak var olmaz aynı zamanda tercih ettiği konut politikalarıyla konut pazarı içinde konut arz ve talebini etkiler, mülk konut ya da kiracılık gibi konut kullanım biçimlerine yön verir.

Devletin pek çok idari kurumuyla, bürokratlarıyla konut politikalarında, konut piyasasında etkin rolü olmasına rağmen konut politikası analizlerinde çoğunlukla ülkelerin ekonomik rejimleri ve politik konjonktürleri dikkate alınır. Oysa konut piyasasını kontrol eden politika araçlarına, hangi toplumsal sınıf lehine karar alınacağına bu alanda yetkili yüksek kademe idari kurumlar, konuyla ilgilenen idari komisyonlar kapalı kapılar ardında bürokratik alanlarda karar verir (Bourdieu ve Christin, 1990, s. 66). Bu anlamda bürokrasi tarafından oluşturulan ve denetlenen bu konut piyasa mantığını anlayabilmek için bu alanın da sosyo-analizini yapmak gerekmektedir.

Nitekim 1960'ların ikinci yarısından sonra Fransız entelektüel alanına damgasını vuran Fransız sosyolog Pierre Bourdieu, Fransız konut politikaları üstünden yaptığı "bürokratik alan çözümlemesinin" konut politikası analizlerine farklı bir bakış açısı getirdiğini öne sürmüştür.

$\mathrm{Bu}$ anlamda bürokrasi alanındaki mücadeleleri "alan, habitus" kavramsal çerçevesiyle açıklayan Bourdieu aynı zamanda bürokrasi mücadelesinde "devletin sağ eli ve devletin sol eli" terminolojisine ayrı bir önem verir. Bu çalışmada 
da Bourdieu kavramsal terminolojisinden hareketle Fransa'da konut alanında köklü değişiklikler meydana getiren "1977 Barrot Kanununun" hemen öncesinde ortaya çıkan bürokratik mücadeleler konu edilmektedir. Çalışmada temel olarak Bourdieu'nün Fransa'da uygulanan konut politikalarını ve buna karar veren aktörlerin tutumlarını, tavırlarını incelediği "The Social Structure of the Economy" (2005) (Ekonominin Toplumsal Yapisl) kitabı ile Rosine Christin ile birlikte yazdığı "La Construction du Marché: Le Champ Administratif et la Production de la Politique du Logement" (1990) (Pazarm İnşası: Bürokratik Alan ve Konut Politikası Üretimi) adlı makalesinden yararlanılmaktadır. Konut piyasası talep ve arz inşasında pek çok aktör olmakla beraber bu çalışmada yalnızca bürokratik alandaki mücadeleye odaklanılmıştır.

Bourdieu bu eserlerinde, konut politikası reformlarının arkasındaki ittifakları ve rakipleri inceleyerek konumsal ve ilişkisel analizler yapar ve bürokratların kendi içindeki güç ilişkilerine yer verir. Buna göre devletin sol eli olarak bir yanda Bayındırlık Bakanlığ ve sosyal konut inşasından sorumlu birimleri, diğer yanda devletin sağ eli olarak "Barre Komisyonu" ve Ekonomi Bakanlığı ve Hazine' deki aktörler analizinde yer alır.

Dolayısıyla bu çalışmada Bourdieu'nün Fransa'da yaptı̆̆ konut politikası incelemesine yer verilerek konut politika analizlerine alternatif bir bakış açısı getirilip getirilmeyeceği sorgulanmaktadır. Konut politikalarının değişen yüzünü yalnızca kapitalist sisteme, sermayedarın çıkarlarına bağlamanın bürokratlar arasındaki güç mücadelelerine bakılmadan analizinin eksik kalacağı öne sürülmektedir. Bu doğrultuda çalışmada, Bourdieu'nün alandaki araştırması temel alınarak konut politikası incelemelerinde çoklu aktör analizi yapılması önerilmektedir.

Bürokratik mücadeleleri ele alan bu makalenin önemi, klasik Weberyan kamu yönetimi anlayışı ile yeni kamu işletmeciliği anlayışının pratikte konut politikası üstünden okumasını yaparak, konut politikası analizlerine farklı bir bakış açısı sunmaktır. Bu doğrultuda çalışmanın birinci ve ikinci bölümünde konut politikası analizinde önemli olan "bürokratik alan" ve "devletin sağ eli ve devletin sol eli" kavramlaştırmaları Bourdieu terminolojisinden yararlanarak açıklanmıştır. Üçüncü bölümde İkinci Dünya Savaşı́ndan sonra 1977 Barrot Kanunu öncesi Fransa'daki konut politikalarının tarihsel seyrine yer verilmiş son bölümde somut olay olarak 1974-1976 yılları arasındaki konut reformu için yapılan bürokratik mücadeleler açıklanmıştır. 


\section{Konut Politikası Analizinde Mücadele Arenası: Bürokratik Alan}

Sahadan elde ettiği ampirik verilerle kavramsal alet çantasını oluşturan Bourdieu'nün alanlar teorisi, her ne kadar akademik yazında ikinci plana atılsa da güç ilişkilerini anlamlandırmada kurucu kuramlardan biridir. Bürokratik alanı ve yapısını kavrayabilmek için önce "alan" (champ) kavramını irdelemek gerekir. Faillerin (agents) manevralar yaptıkları, stratejiler geliştirdikleri ve ulaşılmak istenen kaynaklar (sermaye ya da iktidar elde etmek) için mücadele ettikleri alan; çatışma ve rekabet mekânlarıdır (Bourdieu, 2002, s. 113-120).

Toplumsal dünyayı çeşitli alanların birleşimi olarak algılayan Bourdieu, farklı alanların oldukça özerk olabileceğini belirtir ve karmaşık toplumlarda birbirinden oldukça farklı alanlar olabileceğinin özellikle altını çizer. Örneğin kendine has değerleri, kuralları, çıkarları olan iktisadi alan, akademik alan, bürokratik alan, entelektüel alan ve din alanı gibi pek çok özerk, birbirinden farklı alanlar mevcuttur. Kendi düzenleyici ilkelerini oluşturan bu alanlarda geçerli sermaye türleri de birbirinden farklıdır (Yarım, 2019, s. 60). Aktörlerin bir alanda güç elde edebilmeleri için biriktirdikleri ve kullandıkları kaynaklar ekonomik, kültürel, sosyal ve simgesel olmak üzere dört farklı sermayeden oluşur. Akademik alanda kültürel sermaye önemli bir kaynak iken, ticari alanda ekonomik sermaye ön plana çlkmaktadır (Bourdieu, 1986, s. 242-243).

Alanda tahakküm kurmak isteyen aktörler; işgal ettikleri konuma, kendi ellerindeki sermayeye ve yatkınlıklarına (habitus) göre alanın sınırlarını ve biçimlerini ya değiştirmek ya da korumak için mücadele ederler (Bourdieu ve Wacquant, 2014, s. 26-27). Alan içindeki konumu belirleyen şey bu belirli sermayelere sahip olup olmamaktır. Bourdieu'nün (2006, s. 143) "oyun" metaforu alanlar teorisini daha iyi açıklayacaktır: "Bir oyunda oyuncular (aktörler), onların yatırımları, amaçları, stratejileri vardır. Her oyunun da kendine özgü kuralları, ilkeleri (enjeux) mevcuttur. Oyuncular bu oyunu ellerindeki kartlara (sermayelerine) göre oynarlar. Alan ise bu oyunun oynandığı yerdir. Bütün amaç oyunda hâkimiyet kurabilmek ve dolayısıyla egemen normları belirlemektir. Bu yüzden alanlar birbirinden farklı olsalar da hepsinde ortak olan şey "mücadeledir". İlk mücadele bariyerleri açıp alana yeni girmeye çalışanlar ile alanda önceden konumlanmış ve hâkimiyeti elinde tutanlar arasında meydana gelir (Bourdieu, 2002, s. 115). Alanda daha köklü geçmişe sahip olanlar sermaye birikimleri fazla olduğu için daha avantajlı görünseler de alanda yeni olanlar, egemen olanların yerine geçmek istedikleri için alanın değerlerini ve kurallarını kendi lehlerine çevirmeye çalışırlar (Uluğ, 2013, s. 14). Dolayısıyla 
alan mücadelesi, alana hâkim olan yerleşik failler ile alana yeni katılanlar arasinda gerçekleşir. Yerleşik failler elde ettikleri pozisyonu korumak için muhafaza stratejileri kullanma eğiliminde iken, meydan okuyanlar yeni kurallar dayatabilmek için yıkıcı stratejilere eğilimlidirler (Yarım, 2019, s. 62).

Devlet, genelde sinırları belli, öznesi belirsiz soyut bir varlık olarak görülür. Oysa Bourdieu (aktaran Wacquant, 2007), devletin çapının, sınırlarının, görevlerinin, aldığı şeklin tarih boyunca değişime uğradığını ve bir kurumlar bütünü olduğunu söyler. Bourdieu ve Wacquant (aktaran Wacquant, 2007)'a göre, tek bir bütünlükçü devlet algısını değiştirmek gerekir. Yerine tanımlamaları olan ve kamusal ürün ve hizmetlerin dağıtımını tekeline alan kurumlar bütünü olarak bürokratik alan kavramını koymak daha doğrudur. Bu bakış açısına göre devlet; neyin kamusal mal, neyin kamusal hizmet olduğunu tanımlayan ve dağıtımını gerçekleştiren bürokrasilerden oluşan bir mücadele alanıdır. Hangi kurumun daha fazla bütçesi ya da yetkisi olacak çatş̧ması farklı idari kurumlar arasındaki rekabet sonucu belirlenir.

Nitekim Fransa' da bürokratik alanın doğuşunda dahi failler arası mücadelelerin olduğunu belirten Bourdieu (1997, s. 64)'ye göre bürokratik alanın oluşumunda, alandaki yerleşik failleri yerinden edebilmek için "kamusal yarar" söylemini üreten ve özel çıkarları olan hukukçuların rolü büyüktür. Buna göre; Fransız devrimi öncesinde ve sırasında sınıflar arasındaki hiyerarşiyi altüst etmek ve iktidarı, soylu aristokratlara karşı ele geçirebilmek için entelektüeller mücadele ederler. Kültür ve bilgi sermayesine bağlı olan bu yeni sinıf insan hakları, hukuk, istatistik, ekonomi-politik, dil, yazı gibi yetkinlikleri ön plana çıkarırlar ve okul, üniversite gibi eğitim sistemleriyle kendi bürokratik asillerini yetiştirirler (Bourdieu, Christine ve Will, 2000, s. 8). Yeni ortaya konan sistemin değerlerine, diline, kavramlarına dolayısıyla sembolik sermayesine hâkim olan hukukçular, alanda hükmeden pozisyona geçerler. Çünkü bürokratların güçlü olmalarını sağlayan ellerindeki sermaye, genetik olarak soylu olmak değil “bilgiye" sahip olma sermayesidir. Bu zafer Fransız geleneğinin yeni sınıfı olarak kılıç aristokrasisine karşı cüppe aristokrasisinin (noblesse de robe) zaferidir (Bourdieu, 2016, s. 192).

Bürokratik alandaki önemli olan diğer unsur yüksek kademedeki kamu görevlileridir. Bourdieu'nün tabiriyle "devlet soyluları" olan yüksek kademedeki kamu görevlileri, Fransız yükseköğreniminin en seçkin okullarına (GrandesEcoles) $)^{7}$ giderler ve bu elit dilimde olmanın verdiği meşruiyet ve devlet bürokrasisi içinde işgal ettikleri konumdan ötürü, kendilerini hem emeğin hem de

\footnotetext{
7 Fransa'daki yükseköğrenim, "normal devlet üniversiteleri” ve "grandes ecoles” (büyük, elit okullar) olmak üzere ikiye ayrılır. Normal devlet üniversitelerine parasız ve sınavsız girilebilirken Fransa'ya özgü
} 
sermayenin kişisel çıkarlarını aşabilmiş "tarafsı" sadece "genel kamusal çıkarı" düşünen teknokratlar olarak görürler (Bourdieu, 1991, s. 173). Fakat Bourdieu vd. (2000)'ne göre; devletin hizmetkârları olan bürokratlar, kolektif istek ve çkarlara sahip bir grup insandan oluşmaz. Bürokratik alandaki her aktörün farklı aidiyetlere, habituslara, bakış açılarına, sermayeye sahip olmalarından kaynaklı olarak alanda çekişmeler meydana gelir. Bu yüzden bürokratik alanda aktör incelemesi çok önemlidir.

Bu anlamda Dubois $(2014$, s. 3), Bourdieu'nün kamu politikalarına karar verilme aşamasında, alandaki tüm aktörlerin deneyimlerinin, yetkili faillerin habituslarının (aile yapısı ve gidilen üniversite), inşa edilen algı kategorilerinin önemli olduğunu söyler. Aktörlerin toplumsal konumlarıyla (ekonomik sermayesi yüksek aileden mi kültürel sermayesi ağır basan aileden mi geldiği) uygulanacak kamu politikalarına bakış açlarının benzer doğrultuda olduğunu ileri sürer.

\section{Devletin Sağ Eli ve Sol Eli}

Bourdieu, "Dünya'nın Sefaleti" (2015) (La Misère du Monde) adlı eserinde yüzlerce ylllık mücadelenin sonucunda modern rasyonel devletin "sağ el ve sol el" olmak üzere iki eli olduğunu ifade eder. Bu iş bölümünde kontrol eden, cezalandıran, disipline eden, kıt kaynakları idare eden sağ eldir. Metalaşmanın faili olan ve yeni baskılar üreten piyasa mantığındaki Ekonomi Bakanlığı ve Hazine gibi kurumlar devletin sağ elidir. Wacquant bu sağ ele polisi, mahkemeleri ve hapishaneyi de eklemektedir (Wacquant, 2019, s. 15).

Ekonomik ve kültürel sermaye yoksunu kesimlere yardım eden, bakan, besleyen devletin koruyan eli ise sol eldir. Sağlık, eğitim ve konut gibi korunmaya muhtaç vatandaşlara güvence sağlamayı amaçlayan tüm kamu politikaları devletin sol elini temsil eder (Wacquant, 2007). Bourdieu, devletin bugünkü yeniden kurulumunun sağ ve sol eller arasında bir mücadele olarak görülebileceğini öne sürer.

Dünya'nın Sefaleti (2015) adlı eserinde yaptığı anketlerde Bourdieu, toplumsal yaşamın çelişkilerini kişisel dram şeklinde yaşayan pek çok "kamu görevlisi" olduğunu dile getirir: Yardım kuruluşlarının görevlilerini, eğitimcileri, düşük kademedeki memurları ve diğer eğitim kurumlarının öğretmenlerini “devletin sol eli" olarak tanımlayan Bourdieu (2017, s. 11-12) bu görevlilerin 
sağ el tarafindan verimsiz, müsrif olarak görüldügünü ve kamunun zarar etmesine sebep oldukları için dışlandıklarını dile getirir. Bu kamu görevlileri "devletin sağ elinin" yani Maliye Bakanlarının özel kalemlerindeki uzmanların tam karşıtıdır. Bu yüzden devletin sağ eli, mali denge saplantısı içindeyken bütçe kesintilerinin ağır toplumsal sonuçlarıyla sık sık karşılaşan ve halkla birebir temas içinde olan sol elin ne yaptı̆̆ının farkında değildir.

Kamusal aygıtın Fransa' da "sosyalist yöneticilerle" beraber 1970'lerde gözden düşürülmesi, bireyselleşmeye olan vurgu, "kendin başar devlet sana yardım etmeyecek" düşüncesi (self-help), sosyal devletin yıkımı ve devlete olan inancin yok edilmesi sağ elin sola ele üstün gelmesidir (Bourdieu, 2015, s. 309). Özellikle konut politikası bu çarpışmanın kendini en çok gösterdiği alandır. Konut politikasının hedefi, küçük burjuvazinin devletin ürettiği kolektif konutlardan koparılarak müstakil evinin özel mülkiyetine sahip olması veya mülk sahiplerinden biri olduğu bir apartmana bağlanmasıdır (Bourdieu, 2017, s. 13).

Neo-liberal devrim de Wacquant (2014, s. 1690)'a göre; sağ elin sol eli kontrol etmeye çalışması, hatta üstün gelerek bertaraf etmesidir. Neo-liberalizm, eşitsizliklerin ve onların yarattı̆̆ güvensizliğin sosyal devletle iyileştirilmesinden, devletin sol elinden -polis ve cezayla iyileştirilmesine- devletin să̆ eline geçiştir (Wacquant'dan akt. Kırmızı, 2019, s. 319). Devlet metalaşmayı desteklediğinde toplumsal istikrarı tehlikeye atar çünkü Keynesyen devletin aksine neo-liberal devlet yarı zamanlı, güvencesiz, hakkaniyetsiz çalışma koşullarını normalleştirir. Güvencesiz hayatın normalleşmesi kayıt dışı ekonominin büyümesi anlamına gelir (Wacquant, 2019, s. 14). Tüm bunlar toplumsal kargaşaya neden olurken iktidarlar da meşruiyet sorunlarıyla karşı karşıya kalırlar. Neoliberal devlet bu sorunun üstesinden refah devleti döneminde olduğu biçimde konut, eğitim, sağlık gibi "devletin sol elinin" koruyucu çözümü yerine "devletin sağ elini" uygulamaya sokar ve disipline edici şekilde bu sorunu polis, mahkeme ve hapishanelerle çözer (Bourdieu, 2017, s. 5). Devletin sağ eli devlet desteğiyle şiddetlenen metalaşmanın yol açţğı toplumsal düzensizliği mekânsal hiyerarşinin dibindeki mahallelere hapsederek tepki verir. Böylelikle toplumsal kargaşanın yol açtığı kent çeperlerini ve işçi sınıfı mahallelerini "kentsel hastalık yuvası" şeklinde damgalayarak sorunlu mahallelere dönüştürür. Bunun sorumlusu da neo-liberal devlet değil orada yaşayan insanlar olarak görülür. Toplumsal kargaşa belirli mahallelere hapsedilerek çözülmeye çalışılır (Wacquant, 2014, s. 1690).

"Kentsel hastalık yuvaları" devletin sosyal ve insani yardımları yerine kolluk kuvvetleri ve yargı yoluyla çözümlenir. Hiyerarşinin en altında kalan top- 
lumsal olarak güvensizleştirilmiş bu dezavantajlı sınıflara denetleyici ve düzenleyici şekilde müdahale edilir. Bunu neo-liberal cezalandırma olarak adlandıran Wacquant (2014, s. 1695)'a göre "suça karşı savaş" misyonu devletin kendi otoritesini tayin ettiği, bağımsızlığını ulus-üstü sermaye hareketlerine karşı ortaya koyduğu bir bürokratik tiyatrodur.

Dolayısıyla Bourdieu (2017, s. 12) tanık olunan ve gelecekte de karşılaşılacak olan toplumsal olayların çoğunun devletin alt düzey soylularının (bürokratlarının) devletin üst düzey soylularına başkaldırışı anlamına geldiğini belirtir. Sermaye sahibi bürokratlar, devletin yüksek temsilcileri alanda hâkimiyeti kurabilmek ve kendi kurallarını egemen kılabilmek için sermayeleri doğrultusunda alanda mücadele ederler ve kim kazanırsa onun normları alana hükmeder.

\section{İkinci Dünya Savaşı Sonrası Fransa'da Konut Politikaları (1945-1977)}

İkinci Dünya Savaşı'ndan büyük bir yıkımla çıan Fransa için konut büyük bir sorun olarak ortaya çıkmıştır. 400.000'den fazla bina yıkılırken yaklaşı iki milyon bina da hasar görmüştür (Driant, 2012, s. 1). Bu ağır tablo bir önceki dönemin "bırakınız yapsınlar" şeklindeki konut politikalarının yetersizliğiyle birleşince Fransa'da ciddi sorunlar meydana gelmiştir.

Fransa'da 1944 yılının sonunda İmar ve Şehircilik Bakanlığı (Ministère de la Reconstruction et de l'Urbanisme-MRU) kurulur ve Haziran 1945'ten itibaren, kursal ve kentsel konutların iyileştirilmesi ve bakımı için özel sektör kiralarına vergi konarak ulusal fonlar geliştirilir. Bu oluşum 1948 yılında "Ulusal Konut Geliştirme Fonu'na" (le Fonds National d'Amélioration de l'Habitat-FNAH) dönüşür. Aynı zamanda ucuz konut yapımından ve sosyal konuttan sorumlu birim olan HBM (Habitation à bon marché) daha sonra 1950 yllında çıkarılan bir kanunla HLM (Habitation à loyer modéré) yani düşük fiyatlı kiralık konut kuruluşuna dönüştürülür ve İmar ve Şehircilik Bakanlığı'na bağlanır (Driant, 2012, s. 2). HBM gibi bu birim de devletin ucuz maliyetli konutlardan sorumlu olan birimidir ve sosyal konut politikaları, sadece çok düşük gelirli ailelerin korunmasına yönelik değil aynı zamanda toplumun geniş kesimlerini de hedefler. Buna ek olarak yalnızca dezavantajlı sosyo-ekonomik gruplara da (düşük gelirli çocuklu ailelere) 1948 yılında ALF (l'Allocation de Logement Familiale) adı altında kira yardımları da sağlanmıştır.

1950 yılında devletin konut finansmanı alanındaki etkisini arttırmasını sağlayan diğer bir gelişme ise, özel konut sektörüne kredi ve sübvansiyon sağlamak üzere kurulan Emlâk Kredi Bankası'nın (Crédit foncier de France-CFF) idarecilerinin Ekonomi Bakanlığı'nca atanmasıdır (Olgun, 2017, s. 71). 1950'lerin 
başından itibaren devletin -doğrudan bizzat kendisi- konut üretimi politikasıyla konut arzına önemli ölçüde katkı yapar. Tüm bunlara rağmen 1 Şubat 1954'te Paris' te bir kadının sokakta donarak ölmesi kamuoyunda bir şok etkisi yaratır; konut politikalarının yeterli olmadığını vurgulayan ve devleti göreve çağıran protestolar başlar (Driant, 2012, s. 3). Bu olay üzerine 1955 yılında hükümet yılda 240.000 ucuz konutun inşasını sağlayacak şekilde dönemin İmar Bakanı'nın soy ismiyle anılan "Courant Planı' nı" devreye sokar (Dejoux, Valageas ve Gaimard, 2019). Planla birlikte konut politikasının, yalnızca konut üretiminden ibaret bir faaliyet olmadığını; sosyal donatı ve altyapı imkânlarını da içeren geniş bir perspektif ile ele alınması gerektiğini vurgulayan 7 Ağustos 1957 tarihli Çerçeve Kanunu (Loi Cadre) kabul edilir. Bu kanun doğrultusunda "Öncelikli Gelişme Alanları" (Zones à Urbaniser en Priorité-ZUP) oluşturulup yerel yönetimlerin yetkileri genişletilir. Yerel yönetimlerin banliyölerdeki arsaları ıslah etmeleri, sosyal donatılarını ve altyapılarını sağlayarak arsaları konut tedarikçilerine hazır hale getirmelerinin önü açılır (Olgun, 2017, s. 72).

Öncelikli Gelişme Alanları ile birlikte konut inşası önemli ölçüde artar. 1953 yılında 120.000 konut inşa edilirken 1972'ye gelindiğinde yılda 546.000 konutun inşası tamamlanır. 1957 yllında konut piyasasının \%88' ini elinde bulunduran devletin bu konudaki en baskın idari kurumu HLM'dir ve yeni inşaatların neredeyse \%30'unu elinde bulundurur (Fribourg, 1998, s. 21).

Beşinci Cumhuriyet' in doğuşu ve Charles de Gaulle'nin iktidara gelmesiyle merkezileşen yönetim, Aralık 1958 tarihli bir dizi kararname ile konut sektöründe gerçekleștirilen devlet müdahalesini daha da hızlandırır. "Şehircilik, HLM, Konut Krizi" (Urbanisme, HLM, Crise du logement) başlı̆̆ altında ilan edilen kararnameyle konut alanında iki temel hedef belirlenir (Driant, 2012, s. 3). Birinci hedef, merkezi kentlerdeki çöküntü alanlarının, sefalet mahallelerinin temizlenmesi, yıkılıp yeniden inşa edilmesi (slum clearance) ve daha düşük kalitedeki konutların yenilenmesi iken ikinci hedef de ZUP düzenlemesinin ön gördüğü şekliyle içerisinde büyük apartmanlar, okullar, dinlenme alanları ve alışveriş merkezleri barındıran büyük toplu sosyal konut sitelerine (grands ensembles) yatırım yapılmasıdır (Blanc, 2004, s. 287).

De Gaulle yönetiminin getirdiği pek çok yenilik olmakla beraber konut politikaları açısından önem taşıyan reform "tuğla ve harç" (aide à la Pierre) yardımı adı verilen arz yanlı doğrudan sübvansiyonlarla yeni sosyal konutların inşası için toprak sahiplerinin, sosyal konut tedarikçilerinin finanse edilmesini ön gören düzenlemedir (Blanc, 2004, s. 287). "Aide à la Pierre" politikasıyla beraber devlet sosyal konut inşa edene, konut yatırımcılarına, konutları rehabilite eden bina sahiplerine doğrudan yardım etmenin önünü açmıştır. Öbür yandan bu 
tedarikçilerin, ucuz toplu konut sunabilmeleri için endüstriyel inşa tekniklerini benimsedikleri inşaat sanayiinin teşvik edilmesi politikasını da benimsemiştir (Olgun, 2017, s. 73).

1960'lı yllarda merkezi yönetimin sosyal konutlar için mali teşvikleri arttırması, düşük faizli uzun vadeli kredilerin (45 yıllık) sağlanmasıyla beraber sosyal konutlar özel sektöre göre daha düşük kiralarda sunulabilmiştir. HLM (düşük fiyatlı kiralık konut) kurumunun var oluş nedeni de budur. Bu dönem Fransa'da özel sektörün yeterli olmadığı alanlarda devletin tüm kamusal kaynaklarıyla beraber "sol elini" gösterdiği, arz yanlı sübvansiyonlarla konut piyasasına müdahil olduğu ve toplu konut siteleri ve sosyal konutlar inşa ettiğ $i$ bir dönem olmuştur.

Fakat 1960'ların sonlarından itibaren Fransa' da yavaş yavaş bürokraside ve yönetici sınıfında devletin piyasaya bu kadar müdahil olmasının, bizzat kendisinin sosyal konutları sübvanse etmesinin negatif etkiler yarattığına yönelik şikâyetler başlamıştır. Devletin piyasaya müdahil olmasının toplumsal eşitsizlik yaratth̆̆, yeni inşa edilen sosyal konutların kalitesiz hatta yaşanılmaz olduğu üstünde durulmuştur (Bourdieu ve Christin, 1990, s. 67). Dolayısıyla yönetici elitlerin oluşturduğu komisyonlarda, 1970 yılında Bayındırlık Bakanlığı'nda binalardan sorumlu müdür olacak olan Claude Alphandéry başkanlığında yapılan 6. Yerleşim Planı'nda, danışmanlık yapan Pierre Consigny'nin hazırladığı raporda konut faaliyetlerinde özel finansman kullanım gerekliliği gündeme gelmiş olsa da hiçbirinde "aide à la pierre" (tuğlaya ve harca yardım) konut finansman sistemi sorunun kaynağı olarak görülmemiştir.

1968 yılında Muhafazakâr Partinin de genel seçimlerde ezici bir çoğunluk sağlamasıyla birlikte bürokratik alandaki çıkarlar, stratejiler değişmiş ve devletin sol eli ile devletin sağ eli arasında mücadele başlamıştır. Dolayısıyla Fransa'da başlayan büyük neo-liberal değişim önce kendini konut reformlarında göstermiştir.

Bu bağlamda, "aide à la pierre" arz yanlı sübvansiyonun hemen ardından hanehalklarına yönelik bir kira yardımı olan "Aide Personnalisée au Logement" (APL) finansman modeli öncesi yapılan bürokratik tartısmaları incelemek gerekir. 1973-1976 yılları arasındaki bürokratik mücadele Fransız siyasi yaşamında önemli bir dönüm noktasıdır. Bu yıllar neo-liberalizmin bürokraside nasıl somutlaştı̆̆ının resmi ve Fransa'da da De Gaulle yönetiminin sonudur. 


\section{Bürokratik Alan ve Yeni Konut Politikasının Oluşturulması}

Çatışma ve rekabet mekânları olan bürokratik alanda aktörler, işgal ettikleri konuma göre alanın sınırlarını ve biçimlerini ya değiştirmek ya da korumak için mücadele ederler. Kuralları, ilkeleri kendi yatkınlıklarına göre eğip bükerler ve çatışma alanları oluştururlar. Konut piyasası alanında da failler, meşru biçimde iktidar araçları üstünde egemen olmak için mücadele ederler. Max Weber (1996, s. 132)' in dediği gibi mücadele "meşru şiddet tekelini" ve bunun yanında Bourdieu (2016, s. 18)'nün altını çizdiği gibi "meşru sembolik tekeli" elinde tutmak için gerçekleşir.

Bourdieu ve Christin (1990, s. 66)'e göre, Fransa'da 1974-1976 yılları arasında gerçekleşen ve "1977 Büyük Konut Politikası" kararlarını aldıran süreçte bürokrasi alanındaki çatışmalar etkili olmuştur. Bir yanda statükoyu muhafaza etmeye çalışan yerleşik kurumlar ve yerleşik failler diğer yanda ise değişim isteyen farklı idari kurumlar ve hatta aynı idari kurum içindeki failler arasındaki güç mücadeleleri belirleyici olmuştur.

Bourdieu, Fransa'da neo-liberal dönemle birlikte 1970'lerden sonra yapilan konut politikalarına farklı bir pencereden bakar. Kamu politikalarına karar verilme aşamasında; alandaki tüm aktörlerin deneyimlerinin, yetkili faillerin habituslarının inşa edilen algı kategorilerinin önemli olduğunu dile getirir ( $\mathrm{Du}-$ bois, 2014, s. 3). Sahip oldukları sermaye ve yeteneklerle çarpışan faillerin bu güç ilişkileri konjonktürel faktörlerle şekillenmektedir. Faillerin farklı yeteneklerinin değerleri, hangi grandes-écoles'den (büyük, elit okullardan) mezun olduklarının etkisi, hangi idari kuruluşa, organizasyona bağlı olduklarının gücü dönemin bağlamına göre değişir (Bourdieu, 2005, s. 92). Nitekim her aktör alanda egemenlik kurabilmek için kendi sahip olduğu değerleri kabul ettirme mücadelesine girişir.

Fransa'da konut politikaları konusunda reform yapma düşüncesi 70'lerin başından itibaren dile getirilmeye başlanır. Aide à la pierre finansman modeli, konut konusunda eşitsizliğe ve toplumsal tabakalaşmaya yol açtığı; devlet tarafından sübvanse edilen sosyal konutlar da kalitesiz yapılar olduğu gerekçesiyle eleştirilir. Yürürlükte olan konut yasasının ve HLM'nin, sadece kirasını ödeyebilen orta sınıf hanehalklarını koruduğu; daha kırlgan grupları ve yoksulları dışladığı, üstelik konut yapana arz yanlı sübvansiyonlar yerine "kişilere yapılacak kira yardımlarını"” kamu bütçesi için çok daha hesaplı olduğu genç bürokratlar tarafından dile getirilir. Kişilere yapılacak kira yardımlarının da 
"Aide Personnalisée au Logement" (APL) pazar mantığına göre kişiselleştirilmiş yardım şeklinde yani gelire ve aile durumuna göre olması gerektiği savunulur (Bourdieu ve Christin, 1990, s. 67-68).

Bu bağlamda Bourdieu (2005) "The Social Structure of the Economy" adlı eserinde ve Christin (1990) ile yaptığı çalışmada, 1976 yılındaki kapsamlı konut reformuna götüren dinamikleri açıklamak ister. 1975'te, bürokrasi alanındaki aktörler, kendi kurumsal çıkarlarını korumak amacıyla iki zıt konum arasına yerleşirler: Devletin sol eline karşı devletin sağ eli atağa geçer. Bayındırlık Bakanlığı ve sosyal konut inşaatından sorumlu birimler (HLM) ile temsil edilen, eski konut inşaatı teşvik rejiminin devamın isteyen "sosyal devletçi" pozisyona karşı Ekonomi Bakanlığı, Hazine ve bürokratları, büyük bankalar ile temsil edilen, eski rejimin tamamen terk edilip yeni finansman uygulamaları getirecek bireyselleştirilmiş destek rejimini destekleyen "radikal liberal" pozisyon yer alır (Göker, 2014, s. 293).

Devletin sol eli ve sağ eli ayrımından da öte bürokratik kurumların kendi arasındaki mücadelenin yanı sıra dönüm noktası yaratacak bu yenilikçi reformun arkasında ekonometri bilgisine sahip oldukları için matematiksel modelleri, istatistiki bilgileri ön plana çıaran reformcu mühendis "genç politeknisyenlerle"s, devletin konut sektörüne bu kadar müdahil olmasının kamu kaynaklarında israfa yol açtığını, dolayısıyla çok pahalıya mal olduğunu ve kamu işletmeciliği anlayışına geçmenin gerekliliğini savunan ekonomist "genç enarkları"”9 konjonktürel ittifakı bulunmaktadır (Bourdieu ve Christin, 1990, s. 68). Yeni teknik bilgi tekellerini ellerinde bulunduran ve buna göre eğitim sermayesine sahip bu iki grup kamunun etkin ve verimli olması için devletin konut sektörünü özel sektöre devretmesi gerektiği konusunda uzlaşmışlardır.

1974 yılında Cumhurbaşkanı olmasıyla birlikte Valery Giscard D’Estaing, konut politikasıyla ilgili yenilikçi fikirleri olan genç bürokratlar tarafından bu alanda komisyon kurulması için ikna edilir. Böylelikle 22 Ocak 1975'te Bakanlar Kurulu kararıyla Commission Barre adı altında “Konut Reformu İçin Ulusal Komisyon" kurulur (Bourdieu, 2005, s. 100). Barre Komisyonu'ndaki bürokratik tartş̧maları anlayabilmek ve alanın yapısal çözümlemesini yapabilmek için alanda politikayı yönlendirebilecek etkin ve ağırlı̆ı olan aktörlerin (ya da ku-

\footnotetext{
8 “Politeknisyen" kavramı Fransa' da mühendislik alanında en iyi grandes-écoles'lerden (elit okul) biri olan ve kamuya üst düzey mühendis bürokrat yetiştiren Ecole Polytechnique'de (Mühendislik Okulu) okuyan ögrencilere verilen addır.

9 "Enark" kavramı Fransa' da kamuya üst düzey bürokrat yetiştiren ve grandes-écoles'lerden (elit okul) biri olan Ecole Nationale d'Administration' da (ENA-Ulusal İdare Okulu) okuyan ögrencilere verilen addır.
} 
rumunun) işgal ettiği konumu; çatışmada alınan pozisyonları (mevcut kuralları korumak mı yoksa değiştirmek mi istiyorlar), alandaki ittifakları ve ayrımları açıklamak gerekir.

Buna göre konut reformunda önemli olan idari kurumlardan ilk taraf Ekonomi Bakanlığı, Hazine ve bürokratlarının konut ve kentleşmeyle ilgili Bütçe Genel Müdürlüğü'nün olduğu taraftır. Diğer tarafta ise Bayındırlık Bakanlığı, Bakanlık bünyesinde merkezi ve yerel yapıları inşa etmek ve "aide à la pierre" kapsamında yapılan sosyal konutları yönetmek için kurulan inşaatlardan sorumlu müdürlükler, kentsel planları yapan, inşaat izinleri ve ruhsatları veren Arazi Geliştirme ve Kentleşme Müdürlüğü, yerleşimlerin geliştirilmesi için kurulan ulusal ajans, sosyal konutlardan sorumlu HLM gibi konut politikasının yalnızca konut yapmaktan ibaret bir faaliyet alanı olmadığını; sosyal donatı ve altyapı imkânlarını da içeren geniş bir perspektiften ele alınması gerektiğini vurgulayan idari birimler yer almıştır (Bourdieu, 2005, s. 101).

Bourdieu ve Christin (1990, s. 70-80) yaptıkları çalışma ile bürokrasinin yapısını anlamlandırabilmek ve faillerin davranışlarını çözümleyebilmek için kolektif ve bireysel stratejileri açıklayacak bir model sunmayı hedeflerler. Onlara göre alandaki konumlar nettir ve iki kutba ayrılmıştır: İlk grup Hazine bürokratları, Ekonomi Bakanlığı, özel bankalar eskiden tamamen koparak "bireye yardım" reformlarının kabul edilmesi gerektiğini savunur. Devletin alana müdahil olmasını istemeyen bu taraf "devletin sol elinin" geri çekilmesi gerektiğini düşünür; sosyal konutların iyileştirilmesini ya da arttırılmasını, HLM'nin desteklenmesi için yapılan kamusal yardımları reddeder ve ayrıca konut tedarikinin devletin problemi olmadığını dile getirir.

Öte yandan yürürlükte olan sistemin devamı için direten ikinci grup, Bayındırlık Bakanlığı ve ilgili kuruluşları, sosyal konutlardan sorumlu birim HLM devletin konut ve altyapı yapımından elini çekmesini istemezler. Söz konusu bir idari örgüt olduğunda bu şekilde pozisyon almalarının nedeni bürokratik kurumun kendi varoluşunu koruma içgüdüsüdür. Yani bir idari kurum var oluş amacını, fonksiyonunu kaybetmek istemez. Dolayısıyla inşaatı -özellikle de sosyal konut inşaatını- teşvik etmek ve altyapısını sağlamak için var olan Bayındırlık Bakanlığı ve HLM'nin yürürlükte olan reformun devamını diretmelerindeki sebep budur. Eski reformdan vazgeçilmesi durumunda piyasa mantığına bırakılan konut alanı bu iki kurumun işlevlerinden en önemlisini kaybetmelerine neden olacaktur (Bourdieu ve Christin, 1990, s. 81).

Öte yandan analizin en çarpıcı noktası ve bürokratik devrime neden olan mesele "yenilikçiler" olarak adlandırılan üçüncü grubun devletin sağ el ve sol el karşıtlığının ötesine geçmeleridir. Bayındırlık Bakanlığı'nın kendi içinde, 
farklı düşünen ve kendi kurumunun çıkarlarından farklı olarak reform isteyenlerle iş birliği yapan yeni nesil bürokratlar vardır.

Yukarıda alanlar teorisinde açıklandığı gibi tüm alanlarda ortak olan şey "mücadeledir" ve ilk mücadele bariyerleri aşıp alana yeni girmeye çalışanlarla alanda eskiden beri konumlanana ve hâkimiyeti elinde tutanlar arasında meydana gelir (Bourdieu, 2002, s. 115). Bu yüzden asıl alan mücadelesi, alana hâkim olan ve elde ettikleri pozisyonu korumak için muhafaza stratejileri izleyen yerleşik failler ile alana yeni katılan ve yeni kurallar dayatabilmek için yıkıcı stratejiler geliştiren failler arasındadır.

Nitekim incelenen bu bürokratik alanda da asıl mücadele yerleşik failler ile alana yeni katılan failler arasında gerçekleşir (Bourdieu ve Christin, 1990, s. 8184). Öncelikle alana yeni katılan ve egemen normları yıkmak isteyen failler 2635 yaşları arasında genç, dinamik ve iyi eğitimli yeni nesil bürokratlardır. Cesur ve dinamik olan bu genç bürokratlar yeni görüşlere ve kararlara çok açık olmakla birlikte inisiyatif almaktan da çekinmezler. Dolayısıyla bürokrasinin geleneksel, srradan, hantal rutinlerine mesafelidirler. Ayrıca sosyo-ekonomik anlamda üst sınıftan geldikleri ve pek çok farklı elit okulda, yurtdısında eğitim aldıkları için çevreleri çok geniştir. Bu sosyal sermaye de onlara mezun olur olmaz, uzun yıllar beklemeden prestijli idari kurumlarda işe başlamalarına olanak tanımıştır.

Alandaki yerleşik failler ise uzun yıllardır aynı kurumda çalışan yaşlı bürokratlardır. Geleneksel kamu yönetimi anlayışındaki kariyer sisteminden geldikleri için düşünce yapıları da bu doğrultudadır. Eski kamu yönetim anlayışının ilkelerine sıkı sıkıya bağlı olan bu bürokratların yükselmeleri de kıdem, liyakat ve üstlerinin değerlendirmesiyle olur. Bourdieu (2005) alandaki bu iki farklı bürokratik sermayeye sahip faillerin iki farklı bakış açısı, iki farklı düşünme şekli ve iki farklı bürokratik dünyası olduğunu söyler: Bir yanda bürokratik alanda uzun yıllardır var olmanın getirdiği insanları tanıma ve bilmeden oluşan; yasaları, kuralları, yönetmelikleri iyice benimseyerek ve "uzun süre" aynı işi yaparak elde edilen "deneyim bürokrasisi" (experience bureaucratique) yer alır. Zaman içinde elde edilen bu sermaye yönetimde kıdemli olup tecrübe sahibi olmakla çok yakından ilgilidir. Geleneksel kamu yönetimi anlayışında kurum içi terfiiyle yükselen bu failler belli bir kurum hafızasına sahiplerdir. Yazılı ve resmi kurallara sıkı sıkıya bağlı oldukları için kendi başlarına karar vermez ve yönetmelik dışına çıkmazlar. Diğer tarafta ise teknik, istatistiki, matematiksel bilgiye dayanan eğitim sermayesiyle çevreden kaynaklı sosyal sermayeye sahip olan ve kıdeme bağlı olmadan hızlı bir şekilde yükselen yeni nesil 
bürokratlar yer alır. Uzun yıllar beklemeksizin terfi alan bu bürokratlar teknolojik ve bilimsel bilgiye sahip oldukları için deneyim ya da kurum içi tecrübeye dayalı bilgi tekelini eski bürokratların elinden alırlar ve bürokrasideki ataletin yıkılması gerektiğini dile getirirler. Teknik bilgiden yararlanarak kâr ve zarar modelleri oluşturmaları, ekonometri alanına hâkim olmaları ve rasyonalize edilmiş prosedürler onlara avantaj sağlar (Bourdieu, 2005, s. 113-118).

Dolayısıyla aktörlerin bürokratik alandaki eski/yeni karşıtlığından geleneksel kamu yönetimine karşı harekete geçen yeni kamu işletmeciliği anlayışının yansımasını okumak mümkündür. Alana yeni katılan genç failler alanda tahakküm kurabilmek için kendi ilkelerini ve kendi kurallarını dayatacak yıkıcı stratejiler izlemişlerdir. Eski kamu yönetimi anlayışındaki bürokrasi "hizmet devletinin" bir ürünü olmasından dolayı kurallara, yasalara, yönetmeliklere sıkı sıkıya bağlı, kariyer sistemi katı bir hiyerarşi içinde kurum içi kıdeme dayalı olan, "eskiliğin" çok önemli olduğu bir sistemdir. Weber' in geleneksel bürokrasi anlayışından beri alışı olunan sistem, gayrı şahsilik içinde "devletin büyük hizmetkârlarından" oluşmaktadır. Bu düzeni kanıksamış olan eski bürokratlar kurallara bağlı şekilde inisiyatif almadan kurum kültürüne göre davranmışlardır (Bourdieu ve Christin, 1990, s. 84). Alanda yeni var olan genç, yenilikçi bürokratlar ise Weber' in geleneksel bürokrasi modeline dayalı bu örgütlenme biçiminin günün değişen şartlarında ve ihtiyaçlarında verimsizlik, atalet, hantallık yarattığını dolayısıyla eskiden kopulması gerektiğini öne sürmüşlerdir. Yeni kamu yönetimini savunan bürokratlar risk ve inisiyatif almayı isteyen; rasyonelliğin, matematiksel modellerin, istatistiki verilerin ön plana geçtiği minimal devlet anlayışının yeni örgütlenmesini oluşturdular.

1970'lerden sonra verimlilik ve modernlik özel sektörle, arkaizm ve hantallık da kamu sektörüyle bağdaştırılarak hizmet verilen kişinin artık kullanıcı olarak değil de daha eşitlikçi ve etkin bir ilişki kurmak adına müşteri olarak düşünülmesi istendi ve "modernleşme", kamu hizmetlerinden en kârlı olanların özel sektöre devredilmesi, kamu sektöründeki "hantallı" ve verimsizlikten sorumlu tutulan alt kademe çalışanlarının da tasfiye edilmesi veya hizaya getirilmesiyle özdeşleştirildi (Bourdieu, 2015, s. 309).

Kıdeme dayalı anlayıştan hizmet tecrübesinin zamana bağlı olmaksızın bireysel yetenek, akılcı ve formel işlemler kullanarak kısa zamanda elde edileceğine inanılan anlayışa geçişin ilk adımı konut politikası oluşum sürecinde atılmış oldu. Fransa'da bu değişen konut politikası, sosyal hakları (sağlık hakkı, çalışma hakkı, konut hakkı, eğitim hakkı vb.) savunan refah devleti anlayışı taraftarlarıyla devletin tüm bu alanlardan elini çekmesi gerektiğini düşünen libe- 
ral görüşün taraftarlarının ilk çatıştı̆̆ dolayısıyla neo-liberalizmin kendini hissettirdiği ilk alan olması bakımından önemlidir. Fransa'da "herkesin ihtiyacına göre" prensibinden "hak edene" prensibine geçişin ilk alanı konut sektörüdür. Alanda galip gelen ve kendi kurallarını dayatan neo-liberal düşünce Fransa'da konut alanının özel sektöre devredilmesine neden olur. Sosyal konutların, toplu sitelerin son bulduğu bu dönemde bireylere verilen uzun vadeli kredilerle, borçlandırmalarla ev sahipliği, özel mülkiyet teşviki artırılır.

\section{Tartışma ve Sonuç}

Her eserinde olduğu gibi sahada yaptığı çalışmaları teorik bilgiyle harmanlayan Bourdieu, Fransa'da bir dönüm noktası olan 1977 Barrot Kanununa giden süreci, alanda ortaya çıkan bürokratik mücadeleyi analiz ederek ortaya koyar. Bu çalışmada da Bourdieu'nün konut alanındaki bürokratik analizinden yola çıkılarak konut politikası analizlerinde makroekonomik dinamiklere bağlanılmasının ya da sadece ülkelerin ekonomik ideolojilerinin etkili olduğu ve bunun konut politikalarına, konut kredilerine ve konut finansman sistemine yansıdığı üzerinden yapılan analizlerin eksik kaldığı vurgulanmıştır.

Bu doğrultuda çalışmanın birinci ve ikinci bölümünü oluşturan bürokratik alan analizi, devletin sağ eli ve sol eli tartışması; devlet tahayyülünün yekpare, soyut ve öznesiz bir sistem olarak değil bilakis farklı sermayelere (ekonomik, kültürel, sosyal), eğitim seviyesine, aile yapısına, sosyal çevreye sahip aktörlerden oluşan farklı idari kurumlara sahip bir varlık olarak alglanması gerektiğini belirtir. Çalışmada da vurgulandığı üzere inşaat sektörü sermayedarların ç1karları kadar bürokrasi alanındaki mücadelelerin ve yalnızca merkezin değil yerel güçlerin de çıkarlarının ve habituslarının etkili olduğu bir arenadır.

Bu çatışmanın analiz edilmesinin önemi Weberyen kamu yönetimi anlayışı ile yeni kamu işletmeciliği anlayışının dikotomisinin aktörler arasındaki çatışmalarla somutlaştırılmasıdır. Bununla beraber konut politikasındaki bu analiz refah devletinin sol eli ile neo-liberal, özelleştirmeden yana sağ eli arasındaki mücadeleyi de ortaya koymaktadır. Bourdieu (2015, s. 311)'nün de iddia ettiği gibi devletin sol elinin alandan çekilmesi ve sosyal konut yapımı yerine neoliberal yaklaşımın politikası olarak kişilere doğrudan para yardımı yapması refah devleti anlayışını "basit bir para yardımına" indirger. Ortaya da bu yardımı "hak eden yoksulların" (deservingpoors) faydalanabildiği, eski günlerin dinî hayırseverliğine benzer türden bir devlet hayırseverliği ortaya çlkar. Dolay1sıyla toplumsal tabakalaşmanın sorun edilmediği ve yüksek olduğu Fransa'da var olan eşitsiz dağılım ortadan kaldırılmadan "yardım kültürü" benimsenerek piyasanın yıkıcı etkisini hafifletmeye yönelik politikalar izlenir. 
Sonuç olarak 1980'lerden sonra devletin sosyal konutlardan elini çekerek inşaat alanını özel sektöre bırakması ve rant kapılarını aralaması sermayenin çıkarları kadar, hatta onların politikaya etkilerinden daha kuvvetlice, bürokrasi alanındaki bu mücadelenin bir ürünüdür. Dolayısıyla kamu politikaları incelendiğinde tek taraflı ekonomi-politik incelemelerin yerine çok aktörlü çoklu analizlerin yapılması daha anlamlı sonuçlara neden olacaktır. Örneğin Türkiye'de yine 1980 sonrası ve özellikle 2000 sonrası devletin yeniden ölçeklenmesi yalnızca neo-liberal gelişmelere has bir özellik değildir. Merkezden tasarlanan bir politikadan çok aşağıdaki çatışmaların, yereldeki farklı sermayelere sahip grupların dâhil olduğu, dışlananların tekrar alana müdahil olmak için mücadele ettiği evrimsel bir süreçtir.

Nitekim bugün asıl dikkat edilmesi gereken nokta bundan birkaç yıl sonra milenyum çocukları olan "dijital neslin" yönetim kademesinde, bürokratik alanda, üretim süreçlerine katılması durumunda ortaya çıkacak yeni mücadelelerdir. Bugün sahip olunan algı kategorileri, eğitim, deneyim, bilgi ve eğilimlerle yeni gelen Z kuşağının sermayeleri, bakış açıları, algı kategorileri birbirinden çok farklıdır. Bu nedenle gelecekte politikaların nasıl şekilleneceği ve toplumsal hayata nasıl etki edeceği sorusu alandaki bu yeni faillerin aktör analizleri sonucunda açığa çıkacaktır. 


\title{
Extended Abstract
}

\section{Field of Bureaucratic Struggles and Housing with Bourdieu's Perspective: The Production of New Housing Policy in France}

\author{
* \\ Umut Seren Yarım \\ ORCID: 0000-0001-7799-1744 \\ Eylem Beyazit \\ Muharrem Güneş \\ ORCID: 0000-0002-3432-5722 ORCID: 0000-0002-3187-8233
}

Housing, which is a fundamental part for the formation of cities, remains onthe agenda as one of the main issues of all country policies. As a universal phenomenon from past to present, housing problem is not a problem that can be solved completely in both developed and developing countries. The dimensions and quality of the housing problem vary from country to country, according to development levels and socio-economic structures.

The question of whether housing for society is a shelter or luxury commodity, or part of the social service and welfare system determines the direction of housing policies. According to the determined housing policy, state decide whether this sector is a production activity, a gate of rent or a provision of social infrastructure. Housing policies often transcend their sectorial boundaries and have implicitly broad economic consequences.

The housing market is sustained and controlled, directly and indirectly, by the public authorities. The state lays down its rules of operation through a whole set of specific regulations over and above the normal legal infrastructure and general regulations.

Although the state has an effective role in the housing market with its administrative institutions and bureaucrats, for housing policy analysis the economic regimes and political conjunctures of the countries are mostly considered as the most important determinants. However, public policies that control the housing market are decided behind closed field in which, with different purposes in view and different weapons to hand, where members of the higher civil service with responsibility for housing, construction and finance 
matters, and representatives of private interests in the area of housing and finance confront each other (Bourdieu, 2005, p. 92).

To understand the logic of this bureaucratically constructed and controlled market, it must describe the genesis of the rules and regulations that define its operation. Therefore, this study suggests that the French sociologist Pierre Bourdieu, who left his mark in the French intellectual field after the second half of the 1960s, would bring a different perspective to the analysis of housing policy.

This study aims to consider the historical processes, which are important breaking points in the production of French housing policy, by using Bourdieu's conceptual tools, and aims to analyse the housing policies through the bureaucratic field. In this research, Bourdieu's book entitled "Social Structure of the Economy" and the article with Rosine Christin, "The Construction of the House Market: The bureaucratic field and the production of housing policy" which analyses the housing policies implemented in France and the strategy of agents who decided to do, were used as a reference point. The main purpose of this paper is to specify the place and the influence of the conflict positions of the agents in the bureaucratic field in the process of determining and implementing the housing policy. Bourdieu considers public action as the product of the practices and representations of the agents who are engaged in it, these practices and representations being determined by the objective position of these agents, and therefore by the structure of the relationships which unite them.

Field analysis makes it possible to reveal what socially bases a policy and consequently, to provide a sociological analysis by making it possible to objectify the structure of these corresponding positions, and of these relations.

This is what Pierre Bourdieu gave an example in the above-mentioned works on housing, by analysing the space of positions and positions taken on the principle of the production of policies in this field. This analysis is relatively rarely cited in the works mobilizing the sociology of Bourdieu, and even less by public policy analysts. Moreover, the study of the dynamics of competition and alliances which leads to the reform of housing policy seems to us to constitute a central reference for a positional and relational sociology of public action.

Pierre Bourdieu shows how the change in the value of capital within the bureaucratic field in the second half of the 1970s enabled a conjunctural alliance of young technicians from the Polytechnic and young finance administrators from the "l'Ecole Nationale d'Administration" (National School of Administration) to prevail over the positions previously established in the field 
of housing policies, officials of the Ministry of Equipment, local elected representatives and representatives of mixed economy companies.

As highlighted in the study, the construction sector is a field where struggles over bureaucracy and the habitus of actors are as effective as the interests of capitalists. The importance of analysing these struggles is the concretization of the dichotomy of the Weberian understanding of public administration and the new understanding of public management with conflicts between bureaucratic agents.

Nowadays the main point that needs attention is the new struggles that will arise when the "digital generation" participate in the production processes in the management level, in the bureaucratic field a few years from now. The social, cultural capitals, perspectives and perception categories of the new generation $\mathrm{Z}$ are quite different from the current generation because of their education, experience, knowledge and tendencies. Therefore, the question of how future policies will shape and how they will affect social life will emerge as a result of the correspondence analysis of these new agents in the field.

\section{Kaynakça/References}

Blanc, M. (2004). The changing role of the state in french housing policies: a roll-out without roll-back?. European Journal of Housing Policy, 4(3), 286-287.

Bourdieu, P. (1986), The forms of capital. (Richard Nice, Çev.), John Richardson (Der.), Handbook of theory and research for the sociology of education içinde (s. 241-258), New York: Greenwood.

Bourdieu, P. (1991). Political representation: elements for a theory of political field, Pierre Bourdieu (Der.), Language and symbolic power içinde (s. 171-200). Cambridge: Polity Press.

Bourdieu, P. (1997). De la maison du roi à la raison d'État. Actes de la Recherche en Science Sociales, (118), 55-68.

Bourdieu, P. (2002). Question de sociologie. Paris: Les Editions de Minuit.

Bourdieu, P. (2005). The social structure of the economy. UK: Polity Press.

Bourdieu, P. (2006). Pratik nedenler. (Hülya Uğur Tanröver, Çev.), İstanbul: Hil Yayınları.

Bourdieu, P. (2015). Devlet elini çekince. Levent Ünsaldı (Yayına Hazırlayan), Dünyanın sefaleti içinde, (s. 307-317). Ankara: Heretik Yayınları.

Bourdieu, P. (2016). Devlet üzerine: college de france dersleri (1989-1992). (Aslı Sümer, Çev.), İstanbul: İletişim Yayınları.

Bourdieu, P. (2017). Karşı ateşler-neoliberal istilaya karşı direnişe hizmet edecek sözler. (Sertaç Canbolat, Çev.), İstanbul: Sel Yayıncllı. 
Bourdieu, P. ve Christin, R. (1990). La construction du marché: le champ administratif et la production de la politique du logement. Actes de la Recherche en Sciences Sociales, (81-82), 65-85.

Bourdieu, P. ve Wacquant, L. (2014). Düşünümsel bir antropoloji için cevaplar. (N. Ökten, Çev.), İstanbul: İletişim Yayınları.

Bourdieu, P., Christine, O. ve Will, P. (2000). Sur la science de l'Etat. Actes de la Recherche en Sciences Sociales, 3-11.

Dejoux, V., Valageas, D. ve Gaimard, M. (2019). Panorama de l'évolution des conditions de logement en France depuis la fin des années 1960. Espace, Population, Sociétés, 14.04.2020 tarihinde https://journals.openedition.org/eps/9201\#text adresinden erişildi.

Driant, J. C. (2012). 1850-1995 - Les étapes de la politique du logement en France. Réalités Familiales, 98/99.

Dubois, V. (2014). L'Etat, l'action publique et la sociologie des champs. Swiss Political Science Review 20(1), 25-30.

Fribourg, A. M. (1998). Évolution des politiques du logement depuis 1950. M. Ségaud, C. Bonvalet, \& J. Brun (Der.), Logement et habitat, l'état des savoirs içinde, (s. 223-230), Paris: La Découverte Publication.

Göker, E. (2014). Ekonomik indirgemeci mi dediniz?. G. Çeğin, E. Göker, A. Arlı ve Ü. Tatlıcan (Der.), Ocak ve zanaat: pierre bourdieu derlemesi içinde, (s. 277-302), İstanbul: İletişim Yayınları.

Kırmızı, M. (2019). Loïc Wacquant'a ilişkin notlar üzerinden güncel türkiye okuması denemesi, İdealKent, 10(26), 316-339.

Olgun, H. (2017). Fransa'da konut politikası: tarihi süreç ve bugünkü durum. Emek ve Toplum, 6(14), 69-88.

Uluğ, G. (2013). Pierre Bourdieu'nün sosyolojik yaklaşımından hareketle mizah tüketimi üzerine bir alan çalışması. Yayımlanmamış yüksek lisans tezi, Mersin Üniversitesi, Mersin.

Wacquant, L. (2007). Lö̈c Wacquant ile söyleşi: bourdieu ile devleti düşünmek. Canay Özden, Veysel Fırat Bozçalı, Seda Aydın (Mülakat yapanlar), (Aytuğ Şaşmaz, Çev.), Birikim Dergisi. 06.06.2020 tarihinde https://www.birikimdergisi.com/dergiler/birikim/1/sayi-219-temmuz-2007/2402/loïc-wacquant-ile-soylesi-bourdieu-ile-devletidusunmek/6076 adresinden erişildi.

Wacquant, L. (2014). Marginality, ethnicity and penality in the neo-liberal city: an analytic cartography. Ethnic and Racial Studies, 37(10), 1687-1711.

Wacquant, L. (2019). Kentsel marjinallik ve devletin sağ eli, Aksu Akçaoğlu (Mülakat yapan), İdealKent, 10(26), 11-19.

Weber, M. (1996). Sociologie des religions, (Jean Pierre Grossein, Fransızcaya Çev.), Paris: Gallimard.

Yarım, U. S. (2019). Güç ilişkilerine ve tahakküm alanlarına farkh bir bakış açısı: Pierre Bourdieu düşünümselliği. Yayımlanmamış yüksek lisans tezi, Hatay Mustafa Kemal Üniversitesi, Hatay. 